\title{
Metformin-Induced Hemolytic Anemia
}

\author{
Serap Kirkiz Nese Yarali Ozlem Arman Bilir Bahattin Tunc \\ Ankara Children's Hematology and Oncology Hospital, Ankara, Turkey
}

\section{Key Words}

Metformin $\cdot$ Hemolytic anemia $\cdot$ Diabetes mellitus

\begin{abstract}
Objective: To report a rare side effect of metformin, an oral antidiabetic drug that is used for the treatment of type 2 diabetes mellitus. Clinical Presentation and Intervention: A 17-year-old boy was hospitalized for receiving acute lymphoblastic leukemia treatment that was composed of vincristine, L-asparaginase, daunorubicin, and prednisone. Hyperglycemia was determined without any clinical sign and metformin was started for steroid-induced insulin resistance. On the second day of metformin treatment, the patient's hemoglobin level decreased, and a direct Coombs test was positive for immunoglobulin $G$ but negative for complement. An indirect Coombs test was negative. The glucose-6-phosphate dehydrogenase level was within the normal range. Drug-induced hemolytic anemia was suspected and metformin was discontinued. The jaundice gradually disappeared and there was no requirement for red blood cell transfusions. Conclusion: This case showed that physicians should be aware of the potential side effect of metformin although it is infrequent.

(c) 2013 S. Karger AG, Basel
\end{abstract}

\section{Introduction}

Metformin is the only oral hypoglycemic agent approved for type 2 diabetes mellitus in youth [1]. The most common adverse effects of this drug are diarrhea, dyspepsia, poor appetite, vomiting, lactic acidosis, and metallic taste. Long-term use of metformin substantially increases the risk of vitamin $B_{12}$ deficiency; however, its clinical significance is not known [2]. We report a patient with acute lymphoblastic leukemia (ALL) who developed hemolytic anemia due to metformin therapy.

\section{Case Report}

A 17-year-old boy with B precursor ALL developed steroidinduced hyperglycemia on the 11th day of an intermediate-risk TR-ALL BFM 2000 protocol that included vincristine, L-asparaginase, daunorubicin, and prednisone. Physical examination was unremarkable and evaluation of laboratory tests indicated hemoglobin $(\mathrm{Hb}) 9 \mathrm{~g} / \mathrm{dl}$, WBC $3 \times 10^{9} / \mathrm{l}$, total bilirubin $0.75 \mathrm{mg} / \mathrm{dl}$, and indirect bilirubin $0.55 \mathrm{mg} / \mathrm{dl}$. His fasting serum glucose level was $244 \mathrm{mg} / \mathrm{dl}$ and his insulin level was $22.3 \mu \mathrm{IU} / \mathrm{ml}$. A single daily dose of $250 \mathrm{mg}$ metformin was recommended for insulin resistance and it was planned to increase the dose to twice daily after a week. On the second day of metformin treatment, the serum indirect bilirubin level increased from 0.55 to $1.06 \mathrm{mg} / \mathrm{dl}$ and the $\mathrm{Hb}$ level decreased from 9.2 to $7.8 \mathrm{~g} / \mathrm{dl}$. There was no evidence of hemorrhage, and after red blood cell (RBC) transfusion, the $\mathrm{Hb}$ level increased

\begin{tabular}{ll}
\hline KARGER & $\begin{array}{l}\text { (c) 2013 S. Karger AG, Basel } \\
1011-7571 / 13 / 0232-0183 \$ 38.00 / 0\end{array}$ \\
$\begin{array}{l}\text { E-Mail karger@karger.com } \\
\text { www.karger.com/mpp }\end{array}$ & $\begin{array}{l}\text { This is an Open Access article licensed under the terms of the } \\
\text { Creative Commons Attribution-NonCommercial 3.0 Un- } \\
\text { ported license (CC BY-NC) (www.karger.com/OA-license), } \\
\text { applicable to the online version of the article only. Distribu- } \\
\text { tion permitted for non-commercial purposes only. }\end{array}$
\end{tabular}

Nese Yarali, MD

Ankara Children's Hematology and Oncology Hospital

Diskapi, TR-06110 Ankara (Turkey)

E-Mail neseyarali@yahoo.com 
Table 1. Reported cases of metformin-induced immune hemolytic anemia

\begin{tabular}{|c|c|c|c|c|}
\hline $\begin{array}{l}\text { Study, } \\
\text { first author }\end{array}$ & $\begin{array}{l}\text { Patient } \\
\text { age, } \\
\text { years }\end{array}$ & $\begin{array}{l}\text { Time from the start of } \\
\text { metformin to the onset } \\
\text { of symptoms, days }\end{array}$ & $\begin{array}{l}\text { Direct Coombs } \\
\text { test result }\end{array}$ & Outcome \\
\hline $\operatorname{Lin}[7]$ & 46 & 10 & Equivocal & Recovery \\
\hline Kashyap [2] & 51 & 9 & $(+)(\mathrm{IgG}-, \mathrm{C} 3+)$ & Recovery \\
\hline Meir [9] & 68 & 14 & $(-)$ & Recovery \\
\hline Packer [6] & 56 & $1-2$ & $(+)(\mathrm{IgG}+, \mathrm{C} 3-)$ & Death \\
\hline Blum [8] & 29 & 14 & $(-)$ & G6PD low, recovery \\
\hline Our case & 17 & 2 & $\operatorname{IgG}(+), \mathrm{C} 3 \mathrm{~d}-$ & Recovery \\
\hline
\end{tabular}

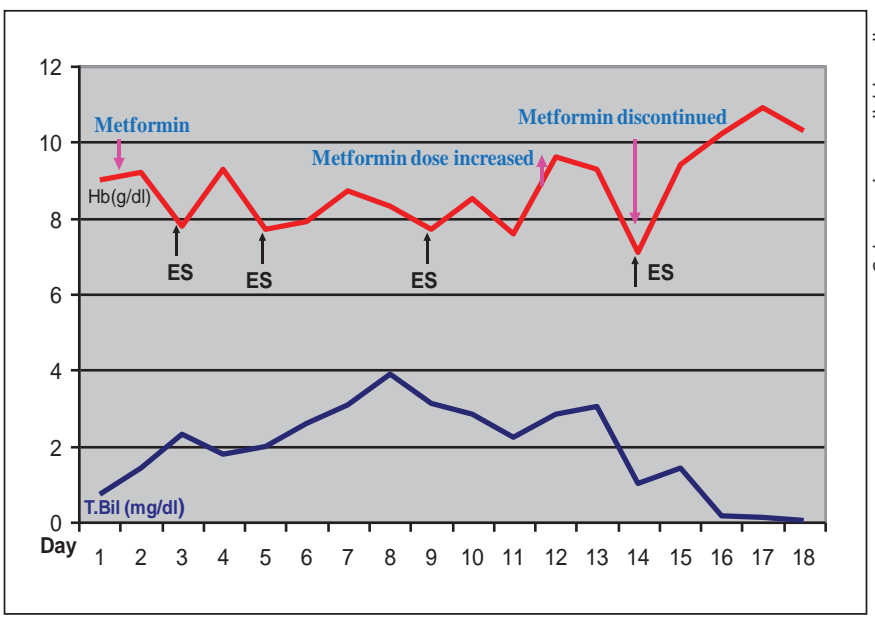

Fig. 1. Hb and biluribin levels after metformin therapy. T.bil = Total bilirubin; ES = erythrocyte suspension.

to $9.3 \mathrm{~g} / \mathrm{dl}$. However, after a few days the $\mathrm{Hb}$ level fell to $7.7 \mathrm{~g} / \mathrm{dl}$ again and a direct Coombs test was positive (2+) with immunoglobulin $\mathrm{G}$ (IgG) but negative with complement 3b (C3b). An indirect Coombs test was also negative. The serum haptoglobulin level was not determined. The reticulocyte count was $3 \%$ and anisocytosis with some microspherocytes was seen in a peripheral blood smear. There were no schistocytes or fragmentated erythrocytes present, and the prothrombin time and the activated partial thromboplastin time were within the normal range (prothrombin time: $16.1 \mathrm{~s}$; activated partial thromboplastin time: 37.9 s). Microangiopathic hemolytic anemia was not considered. Blood reaction was not detected in the urinalysis. Glucose 6-phosphate dehydrogenase (G6PD) activity was within the normal range $(6.5 \mathrm{U} / \mathrm{g} \mathrm{Hb}$; normal: 4.5-13.5 U/g Hb). Creatinine, blood urea nitrogen, aspartate transaminase, and alanine transaminase were also within the normal range. Drug-induced hemolytic anemia was suspected and metformin was discontinued, after which the jaundice disappeared in 3-4 days and therefore there was no requirement for RBC transfusions (fig 1). Hyperglycemia was controlled with diet and further induction and consolidation chemotherapy was completed with no recurrence of hemolytic attack. The calculated Naranjo score of adverse drug reaction probability was 4 , as described in Naranjo et al. [3].

\section{Discussion}

Anemia may occur as either a direct result of leukemia or a side effect of chemotherapy. Drug-induced immunehemolytic anemia (DIHA) is a rare condition. The most common causative agents are antibiotics, especially second- and third-generation cephalosporins $[4,5]$. Purine analogs, particularly fludarabine and cladribine-associated hemolytic anemia, have been reported in patients with leukemia [4]. Hemolytic anemia due to hydrocortisone has also been described [4]. Although our patient received several drugs including L-asparaginase, daunorubicin, and prednisone with metformin, hemolysis ceased shortly after discontinuation of metformin. Therefore, the hemolytic reaction was considered to be due to metformin. Equally important, after cessation of metformin, chemotherapy was continued and completed with no further hemolytic attack.

DIHA can be attributed to many different mechanisms. Some drugs bind covalently to proteins on the $\mathrm{RBC}$ membrane. Hemolytic reaction in vivo is dependent on the presence of the drug and ceases shortly after discontinuation [4]. The other and most controversial DIHA mechanism is immune complex reaction, in which antibodies formed to combined RBC membrane proteins and drugs often activate the complement, leading to acute intravascular hemolysis. DIHA can also be associated with drug-independent antibodies. Such antibodies do not need the drug to be present to obtain in vitro reactions (e.g. fludarabine). In these cases, the drug affects the immune system, causing production of RBC autoantibodies. [4]. Although antibodies against the drug could not be demonstrated, based on the negative Coombs test with complement and no persistence of hemolysis after the discontinuation of metformin, we suppose that the hemolysis was a drug-dependent reaction.

A few cases with metformin-induced hemolysis had been reported and all cases have been in adults [2, 6-9], 
but in this study it occurred in a teenager. Death was reported in only 1 case; the other cases recovered after discontinuation of the drug [6], as in our case. Direct Coombs test results and clinics were variable among these cases (table 1). Metformin may cause G6PD-mediated hemolysis. Although we evaluated the G6PD level during the acute phase of hemolysis, it was within the normal range. G6PD deficiency was ruled out because the patient did not have any previous history of hemolytic anemia and hemolysis did not recur on follow-up. Abrupt onset of hemolysis appeared in 2 cases like our patient; however, severe symptoms of hemolysis were not seen in our patient. This might have been due to suppressed antibody synthesis by administration of prednisone.

When drug-induced hemolytic anemia is involved, the recommendation is to discontinue treatment with the po- tential agent, as was done in this case. Once withdrawn, further treatment with RBC transfusion or plasmapheresis may be warranted in patients with severe hemolysis. Dialysis may also be necessary in patients presenting with renal failure. However, in many cases, supportive care and discontinuation of therapy may be sufficient [5].

\section{Conclusion}

The hemolytic anemia in this patient was induced by metformin. However, metformin-induced hemolytic anemia is rare but this potentially severe side effect should be kept in mind when patients are treated with metformin.

\section{References}

1 Rosenbloom AL, Silverstein JH, Amemiya S, et al: Type 2 diabetes in children and adolescents. Pediatr Diabetes 2009;10(suppl 12):1732.

- Kashyap AS, Kashyap S: Haemolytic anaemia due to metformin. Postgrad Med J 2000;76: 125-126.

-3 Naranjo CA, Busto U, Sellers EM, et al: A method for estimating the probability of adverse drug reactions. Clin Pharmacol Ther 1981;30:239-245.
4 Garratty G: Drug-induced immune hemolytic anemia. Hematology 2009:73-79.

5 Neff AT: Autoimmune hemolytic anemias; in Greer JP, Foerster J, Lukens J, (eds): Wintrobe's Clinical Hematology, ed 11. Philadelphia, Lippincott Williams \& Wilkins, 2004, pp 1157-1182.

-6 Packer CD, Hornick TR, Augustine SA: Fatal hemolytic anemia associated with metformin: a case report. J Med Case Rep 2008;10;2:300.
7 Lin KD, Lin JD, Juang JH: Metformin-induced hemolysis with jaundice. N Engl J Med 1998; 17;339:1860-1861.

8 Blum A, Ghaben W, Slonimsky G, et al: Metformin-induced hemolytic anemia. Isr Med Assoc J 2011;13:444-445.

-9 Meir A, Kleinman Y, Rund D, et al: Metformin-induced hemolytic anemia in a patient with glucose-6-phosphate dehydrogenase deficiency. Diabetes Care 2003;26:956-957. 